\title{
Expression of IFITM1 in chronic myeloid leukemia patients
}

\author{
Cemaliye Boylu Akyerlia ${ }^{\mathrm{a}}$, Meral Beksac ${ }^{\mathrm{b}}$, Michelle Holko ${ }^{\mathrm{c}, \mathrm{d}}$, Mathias Frevel ${ }^{\mathrm{c}}$, \\ Klara Dalva ${ }^{\mathrm{b}}$, Uğur Özbek ${ }^{\mathrm{e}}$, Ender Soydan ${ }^{\mathrm{b}}$, Muhit Özcan ${ }^{\mathrm{b}}$, Gülsüm Özet ${ }^{\mathrm{f}}$, \\ Osman İlhan ${ }^{\mathrm{b}}$, Günhan Gürman ${ }^{\mathrm{b}}$, Hamdi Akan ${ }^{\mathrm{b}}$, Bryan R.G. Williams ${ }^{\mathrm{c}}$, \\ Tayfun Özçelik ${ }^{\mathrm{a}, \mathrm{g}, *}$ \\ a Department of Molecular Biology and Genetics, Bilkent University, Bilkent, 06800 Ankara, Turkey \\ b Department of Hematology, Ankara University School of Medicine, Sihhiye, 06100 Ankara, Turkey \\ c Department of Cancer Biology, Lerner Research Institute, The Cleveland Clinic Foundation, Cleveland, 44195 OH, USA \\ ${ }^{\mathrm{d}}$ Department of Genetics, Case Western Reserve University, Cleveland, 44106 OH, USA \\ e Department of Genetics, Institute of Experimental Medicine, Istanbul University, 34280 Istanbul, Turkey \\ ${ }^{\mathrm{f}}$ Division of Hematology, Numune Hospital, 06100 Sihhiye, Ankara, Turkey \\ g Ayhan Sahenk Foundation, 80670 İstanbul, Turkey \\ Received 4 March 2004; accepted 30 July 2004 \\ Available online 18 October 2004
}

\begin{abstract}
We investigated the peripheral blood gene expression profile of interferon induced transmembrane protein 1 (IFITM1) in sixty chronic myeloid leukemia (CML) patients classified according to new prognostic score (NPS). IFITM1 is a component of a multimeric complex involved in the trunsduction of antiproliferative and cell adhesion signals. Expression level of IFITM1 was found significantly different between the high- and low-risk groups $\left(P=9.7976 \times 10^{-11}\right)$ by real-time reverse transcription polymerase chain reaction (RT-PCR). Higher IFITM1 expression correlated with improved survival $(P=0.01)$. These results indicate that IFITMI expression profiling could be used for molecular classification of CML, which may also predict survival.
\end{abstract}

(c) 2004 Elsevier Ltd. All rights reserved.

Keywords: Chronic myeloid leukemia; IFITM1; RT-PCR; Gene expression

\section{Introduction}

Chronic myeloid leukemia (CML) patients can be divided into three groups of low-risk, intermediate-risk, and highrisk, based on clinical parameters known as NPS [1]. Response of these risk groups to treatment is not uniform [2,3]. For example, low-risk patients respond better to interferon- $\alpha$. Although CML was the first human disease in which a specific chromosomal abnormality $[\mathrm{t}(9 ; 22)(\mathrm{q} 34 ; \mathrm{q} 11)]$ could be linked to the pathogenic events of leukemogenesis [4,5], the gene expression profiles associated with each risk group remain unknown.

\footnotetext{
* Corresponding author. Tel.: +90 312290 2139; fax: +90 3122665097. E-mail address: tozcelik@ fen.bilkent.edu.tr (T. Özçelik).
}

IFITM1, a component of a multimeric complex involved in the trunsduction of antiproliferative and cell adhesion signals [6], was suggested to play a role in the antiproliferative activity of interferons [7]. The sensitivity to inhibition of cell growth induced by interferons was found to correlate with the expression of this gene in various cell lines [8-10]. Furthermore, culture of human RSa cells with interferon- $\alpha$ resulted in increased resistance of the cells to cell killing by X-rays, and increased levels of IFITMI mRNA [11].

We hypothesized that IFITMI could be a molecular marker to identify patients in different CML risk groups based on the observations that this gene has a role in the antiproliferative activity of interferons, and low-risk CML patients respond better to interferon- $\alpha$ treatment. Therefore, we collected blood samples from 60 consecutive CML patients 
classified according to NPS at initial diagnosis, analyzed IFITM1 expression levels by real-time reverse transcription polymerase chain reaction (RT-PCR), and performed KaplanMeier analysis to correlate survival with IFITM1 expression.

\section{Materials and methods}

\subsection{Patients}

Blood was obtained from high-risk $(n=16$, NPS: $1484 \rightarrow 3853$ ), intermediate-risk ( $n=11$, NPS:784 $\rightarrow 1379$ ), and low-risk ( $n=33$, NPS: $21 \rightarrow 708$ ) CML patients, as well as four apparently healthy volunteers, following written informed consent. Patients ranged in age from 20 to 80 years old, with a mean age of $43.4 \pm 13.2$ (mean \pm S.D.), and a male to female ratio of 28-32 (Table 1). CML diagnosis was confirmed in all patients by in situ hybridization (Vysis Inc.) and by RT-PCR (Roche, Molecular Biochemicals) for BCR-ABL fusion. Regardless of risk group assignment, all patients received a short course of hydroxyurea followed by hydroxyurea or interferon during the median follow up duration of 26.5 months. Six patients who did not achieve remission with interferon based on BCR-ABL fusion analysis, received imatinib mesilate sequentially. Four patients (two low, one intermediate and one high-risk) received stem cell transplantation from siblings and are still alive.

\subsection{RNA isolation}

For gene expression analysis in CML it is important to include all types of leukocytes since CML involves cells from multiple heamatopoietic lineages [4]. Therefore, RNA was isolated from the buffy coat. Consequently, our results represent gene expression from whole blood leukocytes. Total RNA was extracted with trizol (Invitrogen) and treated with DNaseI (DNA-free, Ambion) according to manufacturer's instructions [12]. Concentration and purity of the total RNAs were determined on the Beckman spectrophotometer Du640 (Beckman Instruments Inc.). All samples were run on denaturing agarose gel.

\subsection{Real-time quantitative RT-PCR}

The real-time RT-PCR assays were done with the iCycler instrument (BioRad Laboratories) using lightcyclerDNA master SYBR Green I (Roche, Molecular Biochemicals). The sequence of the primers used were: IFITM 1 F-5' -TGCACAAGG AGGAACATGAG-3'; IFITMI R-5'-CTGTTACAGAGCCGAATACC- $3^{\prime}$. GAPDH was used as internal control (F-5'-GGCTGAGAACGGGAAGCTTGTCAT- $3^{\prime}$ and R-5' -CAGCCTTCTCCATGGTGGTGAAGA$3^{\prime}$. Equal amounts of total RNA ( $3 \mu \mathrm{g}$ for each sample) were used in cDNA synthesis (RevertAid First Strand cDNA synthesis kit, MBI-Fermentas), and the quality of cDNA was initially tested by GAPDH RT-PCR amplification using $1 / 40 \mathrm{v}$
Table 1

Patient characteristics

\begin{tabular}{|c|c|c|c|c|}
\hline Risk group/patient no. & Sex & Age & NPS & Disease phase \\
\hline \multicolumn{5}{|l|}{$\operatorname{High}(n=16)$} \\
\hline CML-3 & $\mathrm{F}$ & 45 & 1511 & Blastic \\
\hline CML-7 & $\mathrm{F}$ & 22 & 3853 & Blastic \\
\hline CML-32 & $\mathrm{F}$ & 38 & 2550 & Blastic \\
\hline CML-45 & M & 56 & 1513 & Blastic \\
\hline CML-4 & $\mathrm{M}$ & 42 & 1968 & Accelerated \\
\hline CML-2 & M & 31 & 1495 & Chronic \\
\hline CML-10 & $\mathrm{F}$ & 50 & 1783 & Chronic \\
\hline CML-15 & $\mathrm{F}$ & 29 & 1484 & Chronic \\
\hline CML-23 & M & 28 & 1672 & Chronic \\
\hline CML-55 & M & 53 & 1604 & Chronic \\
\hline CML-58 & $\mathrm{F}$ & 52 & 1514 & Chronic \\
\hline CML-64 & $\mathrm{F}$ & 20 & 1518 & Chronic \\
\hline CML-71 & M & 50 & 1496 & Chronic \\
\hline CML-87 & $\mathrm{F}$ & 51 & 1511 & Chronic \\
\hline CML-89 & M & 55 & 1617 & Chronic \\
\hline CML-91 & M & 37 & 1498 & Chronic \\
\hline \multicolumn{5}{|l|}{ Low $(n=33)$} \\
\hline CML-6 & M & 24 & 142 & Chronic \\
\hline CML-8 & M & 35 & 584 & Chronic \\
\hline CML-12 & $\mathrm{F}$ & 52 & 708 & Chronic \\
\hline CML-13 & M & 40 & 578 & Chronic \\
\hline CML-14 & $\mathrm{F}$ & 46 & 383 & Chronic \\
\hline CML-17 & $\mathrm{M}$ & 63 & 708 & Chronic \\
\hline CML-18 & $\mathrm{F}$ & 25 & 41 & Chronic \\
\hline CML-22 & M & 36 & 635 & Chronic \\
\hline CML-25 & $\mathrm{F}$ & 43 & 259 & Chronic \\
\hline CML-29 & M & 36 & 259 & Chronic \\
\hline CML-31 & $\mathrm{F}$ & 47 & 21 & Chronic \\
\hline CML-46 & $\mathrm{F}$ & 39 & 21 & Chronic \\
\hline CML-51 & $\mathrm{F}$ & 38 & 25 & Chronic \\
\hline CML-54 & $\mathrm{F}$ & 42 & 141 & Chronic \\
\hline CML-56 & M & 46 & 112 & Chronic \\
\hline CML-59 & $\mathrm{F}$ & 32 & 204 & Chronic \\
\hline CML-60 & $\mathrm{F}$ & 65 & 667 & Chronic \\
\hline CML-62 & M & 35 & 497 & Chronic \\
\hline CML-65 & $\mathrm{F}$ & 47 & 204 & Chronic \\
\hline CML-68 & $\mathrm{F}$ & 37 & 210 & Chronic \\
\hline CML-69 & M & 24 & 550 & Chronic \\
\hline CML-70 & $\mathrm{F}$ & 58 & 667 & Chronic \\
\hline CML-74 & $\mathrm{F}$ & 23 & 141 & Chronic \\
\hline CML-75 & $\mathrm{F}$ & 34 & 214 & Chronic \\
\hline CML-78 & M & 49 & 164 & Chronic \\
\hline CML-79 & $\mathrm{F}$ & 26 & 21 & Chronic \\
\hline CML-80 & $\mathrm{F}$ & 33 & 42 & Chronic \\
\hline CML-81 & M & 38 & 217 & Chronic \\
\hline CML-82 & $\mathrm{F}$ & 25 & 105 & Chronic \\
\hline CML-83 & M & 51 & 708 & Chronic \\
\hline CML-84 & $\mathrm{F}$ & 43 & 576 & Chronic \\
\hline CML-85 & $\mathrm{F}$ & 47 & 259 & Chronic \\
\hline CML-86 & $\mathrm{M}$ & 29 & 284 & Chronic \\
\hline \multicolumn{5}{|l|}{ Intermediate $(n=11)$} \\
\hline CML-38 & M & 54 & 784 & Blastic \\
\hline CML-63 & M & 69 & 1017 & Accelerated \\
\hline CML-9 & M & 43 & 830 & Chronic \\
\hline CML-11 & M & 70 & 1025 & Chronic \\
\hline CML-19 & $\mathrm{F}$ & 51 & 1238 & Chronic \\
\hline CML-20 & $\mathrm{F}$ & 51 & 1310 & Chronic \\
\hline CML-28 & M & 57 & 1169 & Chronic \\
\hline CML-30 & $\mathrm{F}$ & 66 & 1379 & Chronic \\
\hline CML-43 & M & 42 & 1102 & Chronic \\
\hline
\end{tabular}


Table 1 (Continued)

\begin{tabular}{cllrl}
\hline Risk group/patient no. & Sex & Age & NPS & Disease phase \\
\hline CML-72 & F & 80 & 912 & Chronic \\
CML-73 & M & 53 & 1080 & Chronic \\
\hline
\end{tabular}

F: female; M: male; NPS: new prognostic score.

of cDNA. A pool of RNA from leukocytes of four healthy volunteers was used as control sample. The PCR reactions were set up in a volume of $20 \mu \mathrm{l}$, containing $5 \mu \mathrm{l}$ of sample cDNA (1:5 dilution of the $\mathrm{RT}$ reaction in nuclease free water), $1 \times$ SYBR Green I dye, $1.5 \mathrm{mM} \mathrm{MgCl}_{2}$, and $5 \mathrm{pmol}$ from IFITMI and $G A P D H$ specific primers. The cycling conditions were as follows: $95^{\circ} \mathrm{C}$ for $30 \mathrm{~s}, 55^{\circ} \mathrm{C}$ for $30 \mathrm{~s}$, and $72^{\circ} \mathrm{C}$ for $30 \mathrm{~s}$ for 45 cycles with initial melting at $95^{\circ} \mathrm{C}$ for $5 \mathrm{~min}$.

Relative expression levels were calculated using the PCR threshold cycle number $\left(C_{\mathrm{T}}\right)$ for each CML and control sample (both of which were normalized according to GAPDH mRNA for differences in amount of total RNA added to the reaction $)$, using the formula $2^{-\left(\Delta C_{\mathrm{T}} \text { sample }-\Delta C_{\mathrm{T}} \text { control }\right)}$ [13-15]. $\Delta C_{\mathrm{T}}$ represents the difference in $C_{\mathrm{T}}$ values between the target and GAPDH transcripts. RT-PCR was performed in duplicates for each sample and average $C_{\mathrm{T}}$ values were calculated. Levels of gene transcripts between high- and low-risk CML were compared using Mann-Whitney $U$-test (Matlab 6 www.mathworks.com mannwhit matlab routine, http:// www.biol.ttu.edu/Strauss/Matlab/matlab.htm) [16]. $P$-values $<0.05$ were considered statistically significant differences.

\section{Results}

\subsection{Real-time RT-PCR results}

We determined the relative transcript level of IFITMI in $60 \mathrm{CML}$ patients by real-time RT-PCR analysis. The results showed that the relative transcript levels were significantly different between the high-risk (ranged between 0.0014 and $0.67 ; n=16)$, and low-risk $(1.2-6.1 ; n=33)$ groups $(P=$ $\left.9.7976 \times 10^{-11}\right)$. The intermediate-risk group $(0.8-5.2 ; n=$ 11) was similar to the low-risk group. The relative expression of IFITM1 in different CML risk groups is shown in Fig. 1.

\subsection{Kaplan-Meier analysis}

We performed Kaplan-Meier analysis in all patients who have follow-up data for at least 26.5 months $(n=24)$. When patient survival was plotted according to IFITMl expression, independently of risk group assignment below or above the cutoff value of 1.0, the low-risk patients demonstrate higher levels of IFITM1 expression compared to the high-risk patients. This finding significantly correlates with survival $(P=$ 0.01 ; Fig. 2). Use of treatment drugs, hydroxyurea or interferon, were similar in all risk groups. Among the nine patients with the lowest IFITMI levels $(<0.5)$, response to interferon was available in only two: both patients were resistant to interferon and imatinib mesilate.

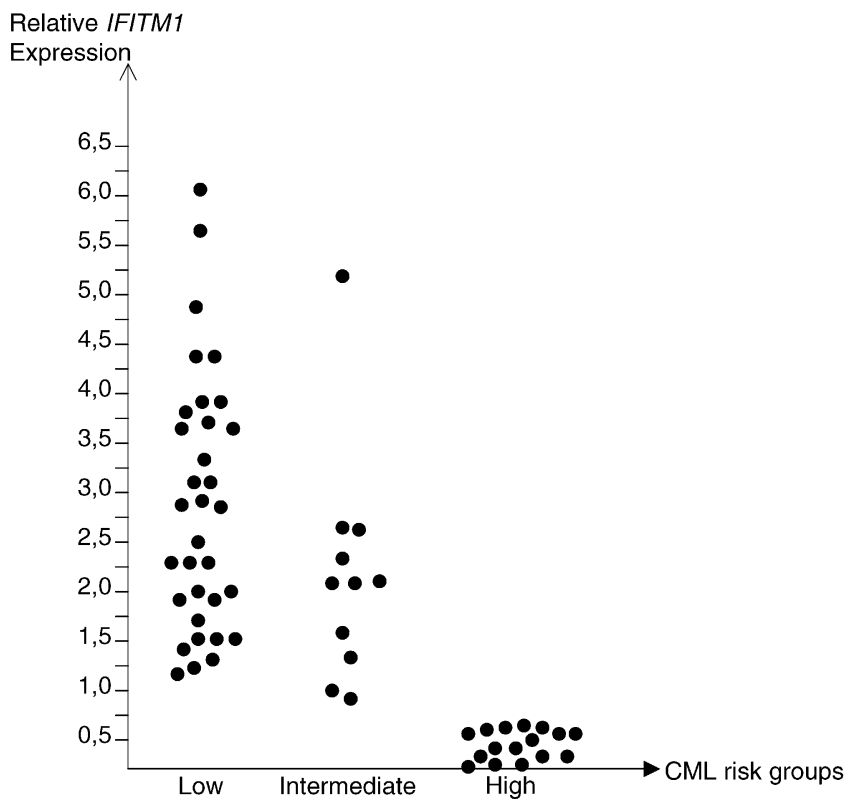

Fig. 1. Relative expression of IFITM1 by real-time RT-PCR in CML risk groups. Levels of gene transcripts between high- and low-risk CML were compared and found to be highly significant $\left(P=9.7976 \times 10^{-11}\right)$.

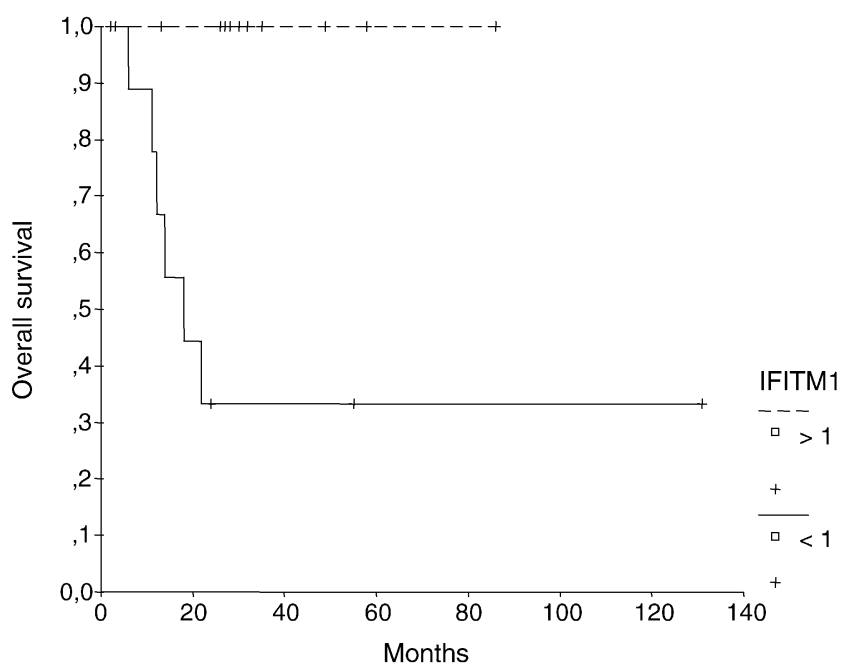

Fig. 2. Kaplan-Meier analysis: Kaplan-Meier plot of overall survival of patients according to IFITMI $(P=0.01)$ expression.

\section{Discussion}

Although gene expression profiles associated with CML have been reported $[17,18]$, to the best of our knowledge, this is the first study in which IFITMI transcript levels at initial diagnosis are correlated with clinical parameters and survival. Currently, in the era of molecularly targeted therapies, use of interferon- $\alpha$ has been widely replaced by imatinib mesilate treatment. However, there are patients who do not respond to imatinib mesilate or develop resistance to it. These patients could be candidates for interferon administration or other treatment modalities. Thus a predictive test, which enables clinicians to select the most suitable treatment agent, 
would be dramatically useful. Our results shows that the expression level of IFITMI is significantly different between the high- and low-risk groups $\left(P=9.7976 \times 10^{-11}\right)$, and higher IFITMI expression correlates with improved survival $(P=0.01)$. For example, high-risk CML patients who are expected to have a high proliferative capacity display decreased IFITMI expression. In an earlier study that was conducted by our group, IFITMI was found to be a differentially expressed transcript between two high-risk and two low-risk patients analyzed by cDNA microarrays [19]. Our results are also consistent with the previous observation that reports IFITMI in the control of cell growth by its antiproliferative activity [6]. Interestingly, interferon induced protein with tetratricopeptide repeats-2 (IFIT2) was found to be the most highly expressed gene during the chronic phase of CML [17]. These results suggest that higher expression of interferon induced genes in CML patients may serve as indicators of interferon- $\alpha$ sensitivity, which in turn may be used as molecular markers to predict response to interferon- $\alpha$ treatment.

IFITM1 expression levels do not appear to be directly correlated with the blast counts of the patients based on the realtime RT-PCR results. For example, the highest blast counts in low-risk patients were within a range of $5-8 \%$, yet their IFITM1 expression levels were higher than all of the high-risk patients including those with the lowest blast counts (4-8\%).

The study reported here constitutes an initial attempt to identify candidate CML risk group indicator genes using expression profiling, and this profiling may lead to the development of a gene based classification system for CML which appears to be highly correlated with the clinical scoring at the time of initial diagnosis, and may predict disease outcome.

\section{Acknowledgements}

We thank the patients who took part in this study. This work was supported by grants from Bilkent University Research Fund, TÜBA, TÜBİTAK-SBAG-2513, and National Institutes of Health Grants R01-AI34093 and PO1-CA62220. C.B. Akyerli is a recipient of TÜBITTAK-BAYG NATO A2 fellowship. M. Beksac is a member of TÜBA (Turkish Academy of Sciences).

\section{References}

[1] Hasford J, Pfirrmann M, Hehlmann R, Allan NC, Baccarani M, Kluin-Nelemans JC, et al. A new prognostic score for survival of patients with chronic myeloid leukemia treated with interferon alpha. J Natl Cancer Inst 1998;90:850-8.
[2] Alimena G, Lazzarino M, Morra E, Mancini M, Cedrone M, Montefusco E, et al. Clinical and cytologic characteristics of blastic phase in Ph-positive chronic myeloid leukemia treated with $\alpha$-interferon. Leukemia 1996;10:615-8.

[3] Kloke O, Opalka B, Niederle N. Interferon alpha as primary treatment of chronic myeloid leukemia: long-term follow-up of 71 patients observed in a single center. Leukemia 2000;14: 389-92.

[4] Faderl S, Talpaz M, Estrov Z, O’Brien S, Kurzrock R, Kantarjian HM. The biology of chronic myeloid leukemia. New Engl J Med 1999;341:164-72.

[5] Deininger MWN, Goldman JM, Melo JV. The molecular biology of chronic myeloid leukemia. Blood 2000;96:3343-56.

[6] Deblandre GA, Marinx OP, Evans SS, Majjaj S, Leo O, Caput D, et al. Expression cloning of an interferon-inducible $17-\mathrm{kDa}$ membrane protein implicated in the control of cell growth. J Biol Chem 1995;270:23860-6

[7] Gutterman JU. Cytokine therapeutics: lessons from interferon alpha. Proc Natl Acad Sci USA 1994;91:1198-205.

[8] Knight Jr E, Fahey D, Blomstrom DC. Interferon-beta enhances the synthesis of a 20,000-dalton membrane protein: a correlation with the cessation of cell growth. J Interferon Res 1985;5: 305-13.

[9] Evans SS, Lee DB, Han T, Tomasi TB, Evans RL. Monoclonal antibody to the interferon-inducible protein Leu-13 triggers aggregation and inhibits proliferation of leukemia B cells. Blood 1990;76:2583-93.

[10] Evans SS, Collea RP, Leasure JA, Lee DB. IFN-alpha induces homotypic adhesion and Leu-13 expression in human B lymphoid cells. J Immunol 1993;150:736-47.

[11] Kita K, Sugaya S, Zhai L, Wu YP, Wano C, Chigira S, et al. Involvement of LEU13 in interferon-induced refractoriness of human RSa cells to cell killing by X-rays. Radiat Res 2003;160: 302-8.

[12] Frevel MAE, Bakheet T, Silva AM, Hissong JG, Khabar KSA, Williams BRG. p38 mitogen-activated protein kinase-dependent and independent signaling of mRNA stability of AU-rich elementcontaining transcripts. Mol Cell Biol 2003;23:425-36.

[13] Pfaffl MW. A new mathematical model for relative quantification in real-time RT-PCR. Nucl Acids Res 2001;29:2002-7.

[14] Livak KJ, Schmittgen TD. Analysis of relative gene expression data using real-time quantitative PCR and the $2^{-\Delta \Delta C_{\mathrm{T}}}$ method. Methods 2001;25:402-8

[15] Tanaka S, Kobayashi I, Utsuki S, Oka H, Fujii K, Watanabe T. $\mathrm{O}^{6}$. methylguanine-DNA methyltranspherase gene expression in gliomas by means of real-time quantitative RT-PCR and clinical response to nitrosoureas. Int J Cancer 2003;103:67-72.

[16] Mann HB, Whitney DR. On a test of whether one of two random variables is stochastically larger than the other. Ann Math Stat 1947; 18:50-60

[17] Ohmine K, Ota J, Ueda M, Ueno S, Yoshida K, Yamashita Y, et al Characterization of stage progression in chronic myeloid leukemia by DNA microarray with purified hematopoietic stem cells. Oncogene 2001;20:8249-57.

[18] Li H, Jie S, Zou P, Zou G. cDNA microarray analysis of chronic myeloid leukemia. Int J Hematol 2002;75:388-93.

[19] Akyerli CB, Beksac M, Holko M, Frevel M, Dalva K, Gürman G, et al. Analysis of high and low risk chronic myeloid leukemia by gene expression profiling. Blood 2002;100:365a (abstract). 